\title{
HYDROMORPHOLOGICAL EFFECT OF INTRODUCING SMALL WATER STRUCTURES IN RIVER RESTORATION - THE EXAMPLE OF PBHS IMPLEMENTATION
}

\author{
Tomasz Kałuża', Krzysztof Szoszkiewicz², Ewelina Szałkiewicz' \\ 1 Department of Hydraulic and Sanitary Engineering, Poznań University of Life Sciences, Poznań, Poland, \\ e-mail: tomasz.kaluza99@gmail.com; sonnenbergewelina@gmail.com \\ 2 Department of Ecology and Environmental Protection, Poznań University of Life Sciences, Poznań, Poland, \\ e-mail:kszoszk@up.poznan.pl
}

Received: 2016.01.07

Accepted: 2016.03.04

Published: 2016.04.01

\begin{abstract}
The work attempts to determine the impact of small hydrotechnical structures on channel hydromorphology as a measure of river restoration. The experiment was set up in Flinta River in Polish lowland where extensive hydromorphological survey was competed. At the first stage of restoration project containers filled with plant clumps working as sediment traps (plant basket hydraulic structures - PBHS) were introduced. Those structures were relatively small but at the same time, large enough to change the river flow efficiently - working like low crested weirs. Two year monitoring program provided information about the impact of introducing such structures on river morphology and explained the PBHS impact on flow pattern of the river.
\end{abstract}

Keywords: river restoration, hydromorphology, river flow pattern, hydrodynamic conditions, plant basket hydraulic structure.

\section{INTRODUCTION}

River restoration refers to a variety of measures and practices aimed at restoring modified watercourses back to the natural state. It is based on a range of ecological, physical, spatial and management elements influencing the channel as well as adjacent areas [Żelazo 2006]. The restoration schemes should stimulate natural fluvial processes and be beneficial for biodiversity, recreation, flood management and landscape development.

A wide range of measures are utilised in various river restoration schemes. The engineering structures designs for river restoration should be built of natural materials, preferably on the local origin [Żelazo 2006]. Besides, implemented materials must be resistant to various conditions as unstable water level, the weather, water flow and mechanical impact of floating wooden debris and ice [Wołoszynet al. 1994]. A wide range of engineering structures and bank reinforcements can be efficiently constructed of pieces of wood, trunks andbranches as well asnatural stone.

In Polish literature there are several examples of restoration schemes implementations utilizing natural materials. One of them was the Kwacza river (Northern Poland) where a variety of measures were implemented to stimulate riverbed morphology enrichment. They utilised fallen trees as microhabitats for a variety organisms. Moreover, they used stones rip-rap on brush mattresses, wooden trunks and deflectors to diversify the flow and to create additional shelter for fish. To stabilize the riverbank trunks were implemented (Figure 1). Several tons of gravel and sand were also deposited in the channel bed to stimulate salmonid's spawning [Obolewski et al. 2009].

The restoration scheme was also introduced in the Basin of Middle Biebrza in the triangle Jegrznia - Elk - Woźnawiejski Channel [Byczkowski and Okruszko 1996], where a wide range of engineering measures utilising wood and stone material was utilised (Figure 2). 


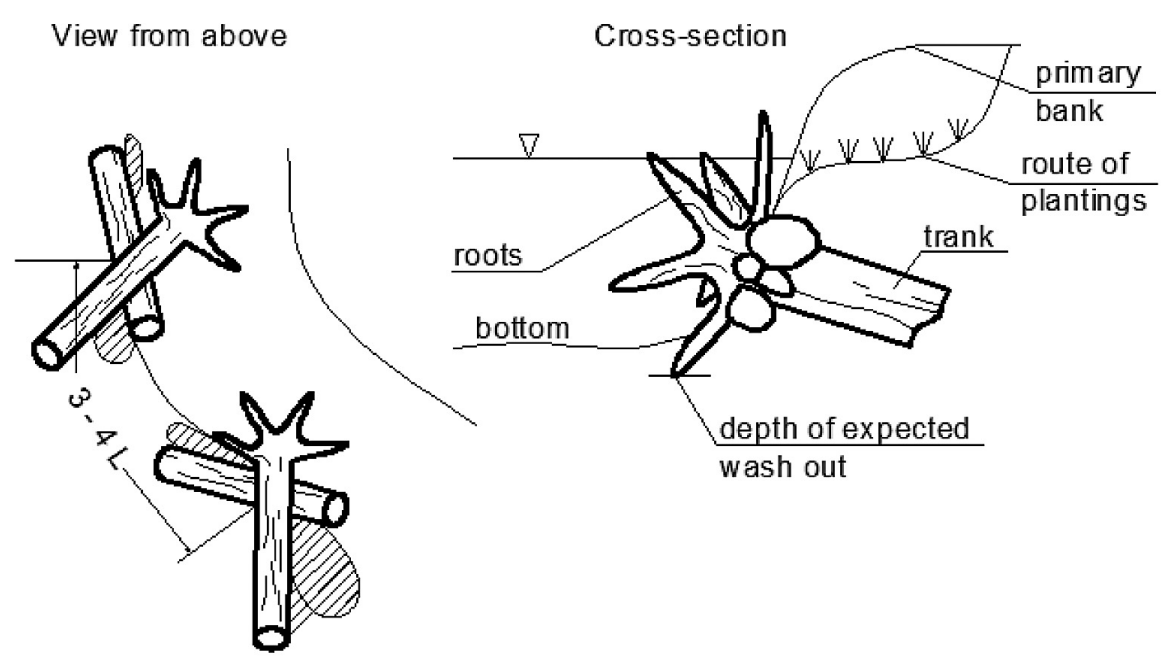

Figure 1. Bank reinforcement with the use the wooden trunks
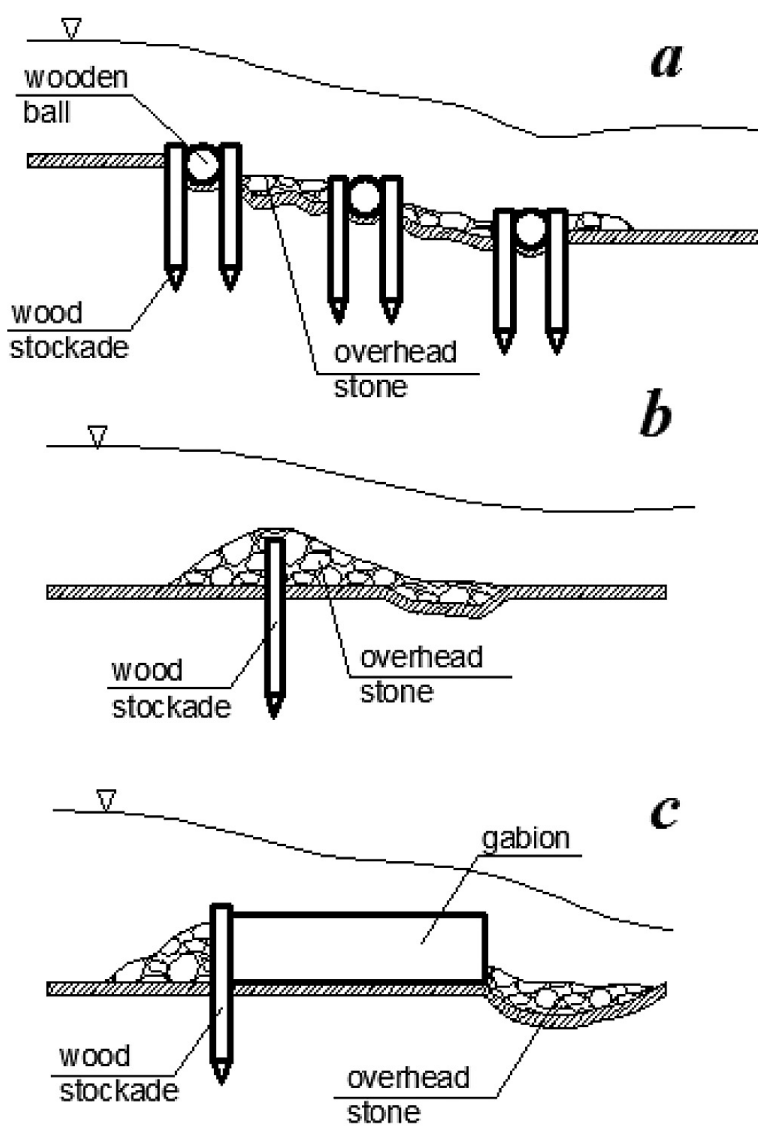

Figure 2. Construction of thresholds stabilizing the bottom and longitudinal profile a) cascade of thresholds wood or wood-fascine, b) the stone threshold, c) the threshold made fromgabion

An example of the use of small hydrotechnical structures in restoration is the Rudnia River (lowland river in East Poland) [Jedryka 2003]. Rudnia had a strongly meandering character before drainage program was implemented in 1960 's when it was regulated in the estuary reach. The concept of restoration assumed a natural con-
View

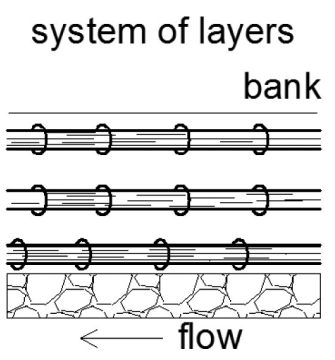

diagonal layout

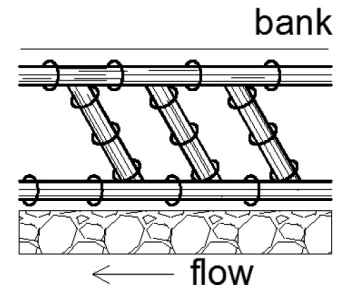

Figure 3. Strengthening of slopes by fascine [according to Bednarczyk and Duszyński 2008]

nection between the main channel and its historic floodplain shift back with the previous shape and dimensions of the channel. It was achieved with a wide fascine installation for slope reinforcement and strengthening (Figure 3).

The use of a range of technical measures presented in the above examples, shows the efficiency of smallchannel structures river restoration. They are resistant and relatively easy to implement, and a wide range of available constructions ensures that the restoration scheme can be adopted to local conditions. Moreover, the use of natural materials is cheaper in many cases and is beneficial for local biodiversity [Żelazo and Popek 2002].

Structures should never be viewed as a substitute of good riparian management and bank vegetation development, which are able to significantly decrease the destructive impact of flowing water. Such bioengineering techniques are especially efficient in riverbank erosion control, by strengthening and binding the soil particles with root system [Bolesta 1964]. The introduction of biological forms of bank protection is beneficial 
for the nature. The vegetation developing on riverbanks improves landscape and delivers habitat for many animal species. Moreover, the riverbank sward purifies the water mainly by sediment absorption and nutrient intake.

The restoration efficiency caused by vegetation depends on species composition. Introduced plants should be resistant to variable water level, temporal or permanent submersion, sun exposure and water flow. Moreover, growth rate, competitiveness and surface coverage ability must be considered while selecting species for restoration schemes. Plants used for bank reinforcement should be characterized by [Bolesta 1964]: a strong root system, resistance to temporary flooding, availability on market and low cost of seed material, simple planting technology, rapid population growth, long growing season, resistance for cutting. The introduced species must also correspond to the existing local vegetation. The most popular species utilised in river bank reinforcement, besides willows and wickersare: Phalaris aroundinacea, Glyceria maxima, Schoenoplectus lacustris, Carex acuta, Phragmites australis, Typha latifolia, T. angustifolia, Sparganium erectum, Rumex hydrolapathum and Alnus glutinosa [Borys 2005].

Growing plants in river restoration are not limited to banks. Introducing vegetation inside the channel diversifies the flow and stimulates several fluvial processes connected with bank erosion and sediment deposition. This paper attempts to determine the impact of introduction small hydrotechnical structures consisting of vegetation on channel hydromrphology. The experiment was set up in the Flinta River in lowland Poland where extensive hydromorphological survey was carried. The introduced measures were originally designed structures called Plant Basket Hydraulic Structures (PBHS). Two year monitoring program provided information about their impact on river morphology.

\section{The Flinta River}

The Flinta River is a lowland river in Central Poland with sandy substrate (Figurte 4). It is a right tributary of the Welna River. Its length is about $17 \mathrm{~km}$ and the total catchment area is $345.47 \mathrm{~km}^{2}$.

Due to valuable fluvial vegetation and fish fauna of the Flinta and the Welna Rivers an extensive monitoring program was carried out between 2012 and 2013 on these watercourses. The basin on these research of the Flinta and Wełna Rivers restoration program was prepared [Szoszkiewicz et al. 2014]. To improve the hydromorphological status, several restoration measures of the most degraded parts were proposed. It was found that comprehensive restoration requires large scale efforts - thirteen various technical and biological measures were proposed to stimulate fluvial pro-

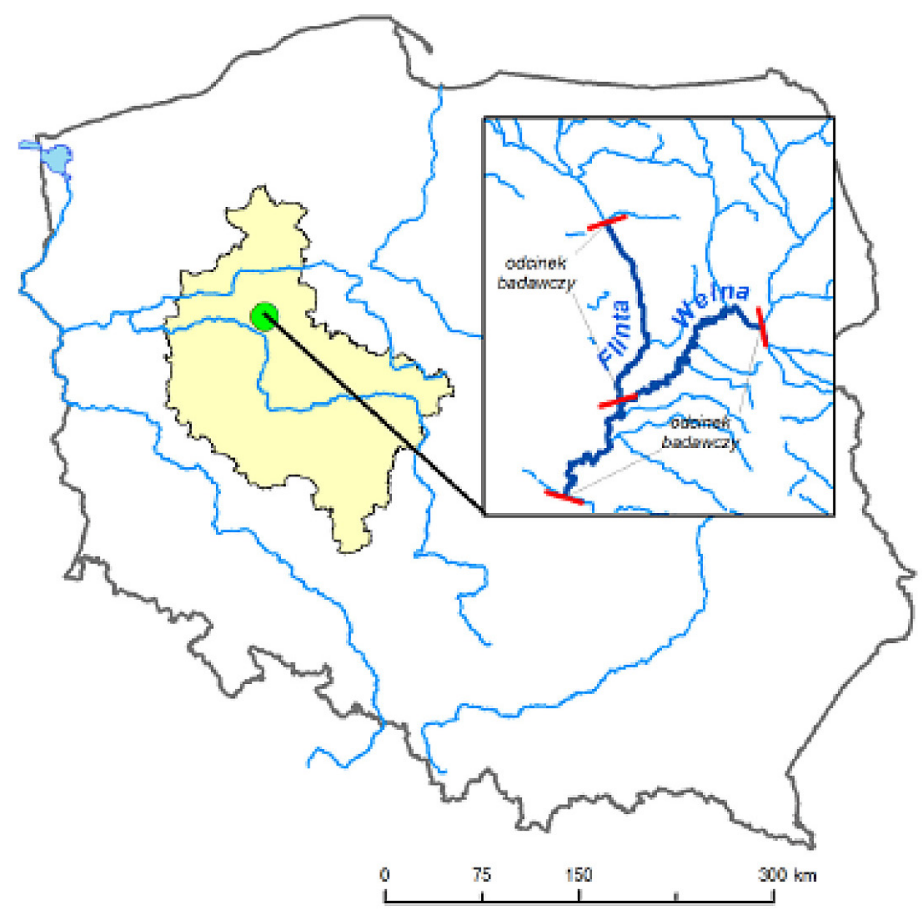

Figure 4. Flinta River catchement 
cesses and to improve habitat for the development of living aquatic organisms in rivers. Studies have shown parts of the rivers where restoration can be particularly effective to improve hydromorphological status. Hydraulic analysis proved that the proposed activities do not significantly deteriorate high water flow and do not increase the flood risk.

\section{METHODS}

Basing on the Flinta and Welna Rivers restoration program [Szoszkiewicz et al. 2014] a set of measures was introduced in 2014. First, a row of clumps of emerged plants (plant barriers) set in perforated containers was introduced named as: Plant Basket Hydraulic Structures (PBHS). These structures are relatively small but working like low crested weirs and changing the river flow pattern.

PBHS were introduced in the cross section km 0+100 near the village Rożnowo. Every container was made of plastic (dimensions 70x40x30 $\mathrm{cm}$ ) and it was filled with river gravel and concrete blocks (Figure 5). Every container was filled with willow cuttings (approx. 30 pieces per basket). The set of containers was distributed in the channel bed in the transect across the river. The distance of $1 \mathrm{~m}$ between each container was kept [Radecki-Pawlik 2014].

Before starting the experiment hydrometric measurements were completed across the transect without trays (Figure 3a). Cross-sectional geometry was defined as well as the slope of surface and velocities distribution. After installing containers hydrometric measurements were recorded systematically during nearly two years of exploitation. Changes of sediment grain size were analyzed. Additionally, the amount and size of plant debris accumulated by PBHS was measured. Hydromorphological changes and development of natural plant succession was estimated as well. Finally, we carried out hydraulic calculations treating PBHS as hydraulic structures which have influence on changes on river pattern alternation as well as on river hydrodynamics.

The hydrometric measurements of water flowing in an open channel [Radecki-Pawlik 2014, Carling et al. 2006], were conducted with an electromagnetic flow sensor, the FLAT Model 801 from Valeport. It allows the measurement of water flow velocity in the range from $0.001 \mathrm{~m} \cdot \mathrm{s}^{-1}$ to $10 \mathrm{~m} \cdot \mathrm{s}^{-1}$. They also measure the velocities of water just above the river and stream bed, which is important not only for the movement of sediment [Radecki-Pawlik et al. 2014] but also in the case when one takes into consideration the presence of invertebrates. By using the device, a few measurement divisions were determined in the field, which consisted of the following parameters: average velocity, maximum velocity and stream bed filling.

The measurements can be carried out either continuously or as an averaged measurement over a predetermined time interval. Some of the measurements were carried out before the construction of the sediment traps and the remaining ones were taken after the installation of the

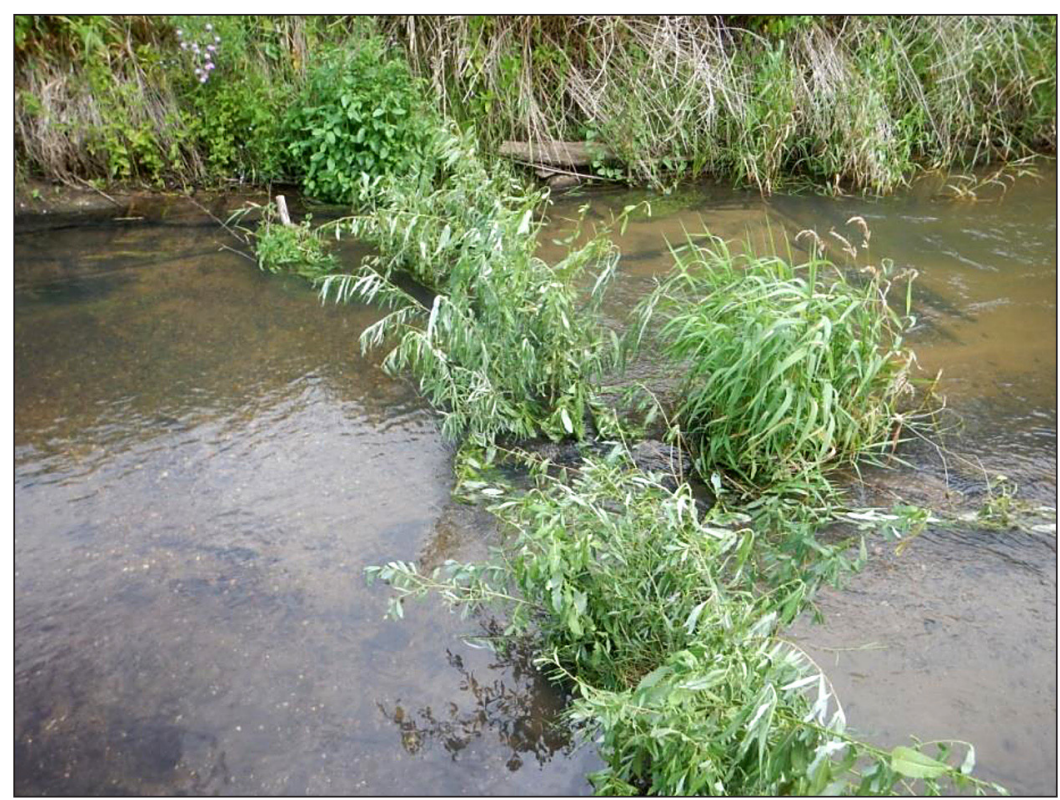

Figure 5. Plant Basket Hydraulic Structures on the Flinta River 
traps. The measuring points are shown in Figure 6. The results are gathered into a group of measurement points from the period when the river course was undisturbed, with no sediment

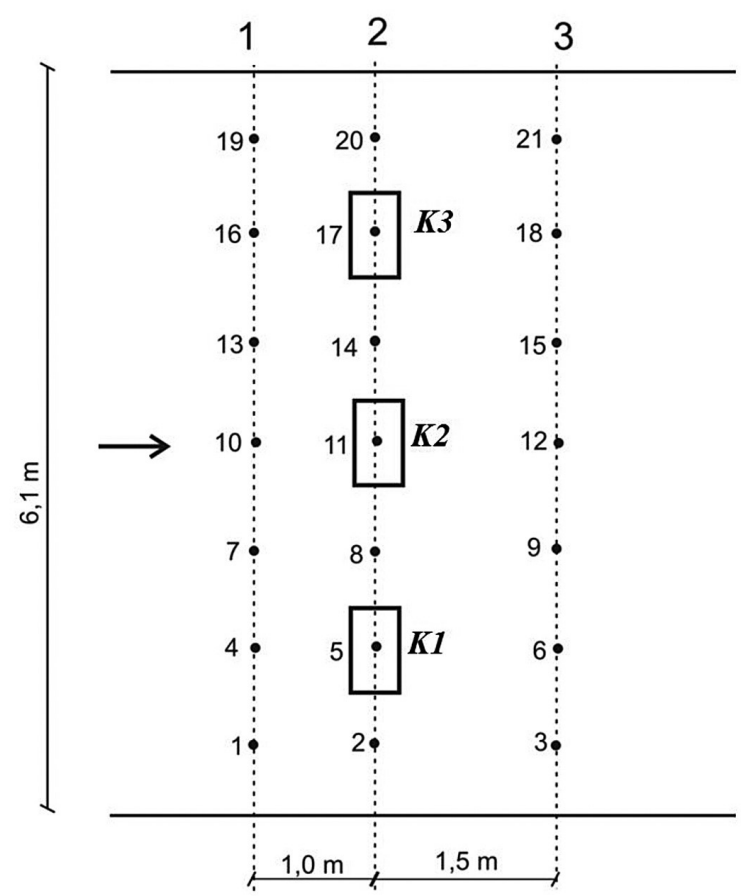

Figure 6. Investigated vegetative baskets and the measuring points along the Flinta in the case study research reach traps (2 August 2013), and from the period after the installation of the sediment traps - (25 September 2013 and all of the measurements in 2014). The results of the calculation of basic hydraulic parameters $\left(t, V^{*}, R e, F r\right)$ were used to analyse the hydromorphological conditions of the Flinta river in the measuring sections [Kałuża et al. 2015].

\section{RESULTS AND DISCUSSION}

River bed alterations and changes of the hydraulic conditions just below introduced PBHS were detected in the result of direct measurements. Observed changes the river bed morphology between 25.09.2013 and 2.10.2014 are shown in the Figure 7. Erosion and accumulation process of bottom material were recorded. Differences in the level of the riverbed were about $13 \mathrm{~cm}$.

Considerable changes also involved the values of shear stress After the installation of the PBHS these values increased significantly (Figure 8 ). The average shear stress before the installation of baskets was $0,048 \mathrm{~N} \cdot \mathrm{m}^{-2}$. After the installation (and after one year in operation), this value rose maximally to $0,42 \mathrm{~N} \cdot \mathrm{m}^{-2}$. This indicates a local increase of flow resistance within the baskets. a)

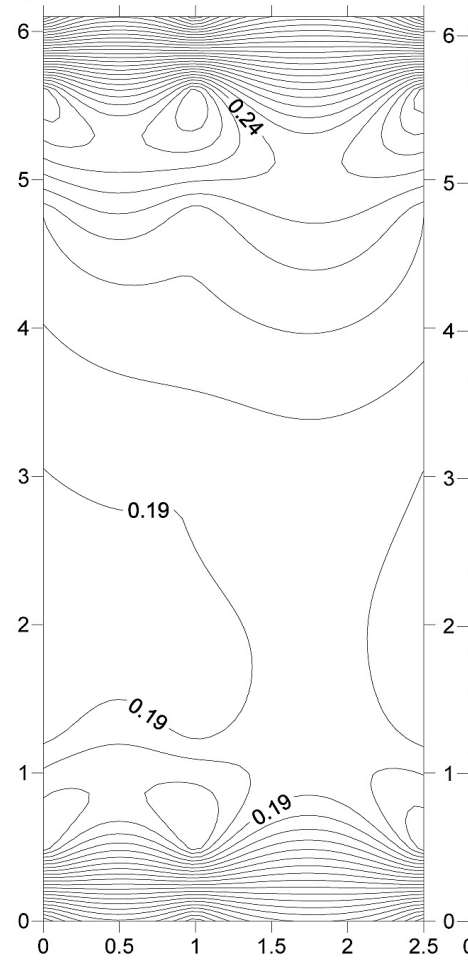

b) c)

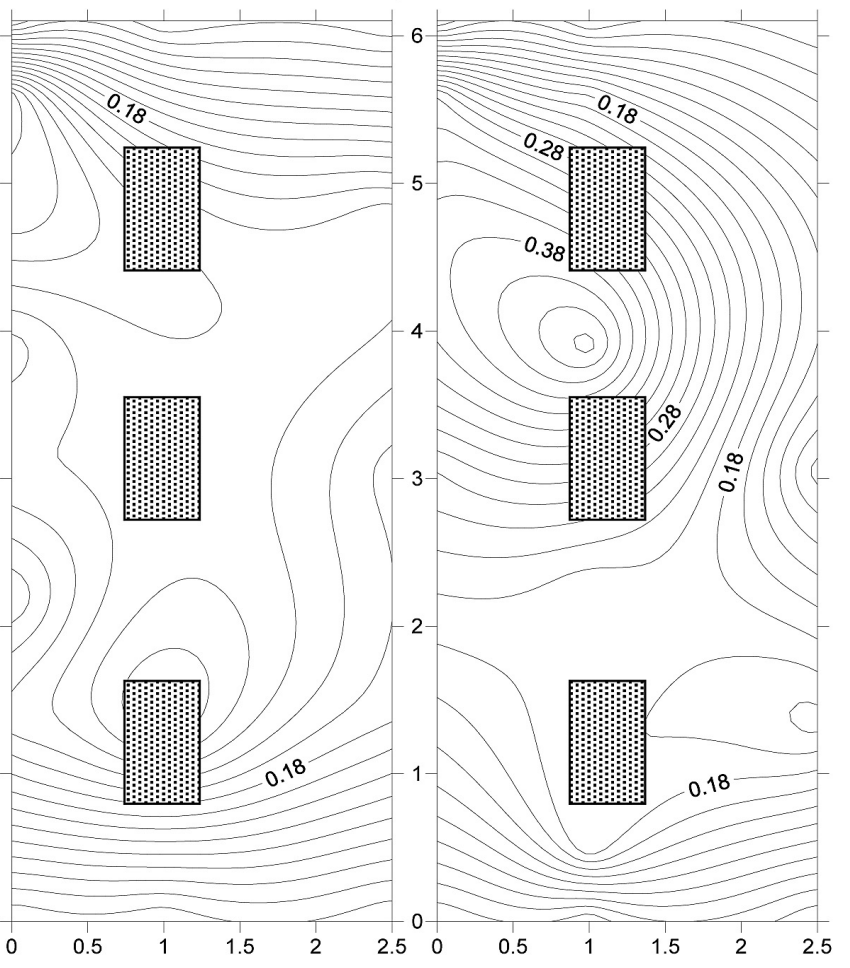

Figure 7. Changes in the riverbed morphology in the result of PBHS introduction:25.09.2013 - before introduction (Fig 7a), 25.09.2013 - shortly after introduction (Fig 7b) and 2.10.2014 -one year after introduction (Fig 7c).

Geometrical dimensions are given in metres 


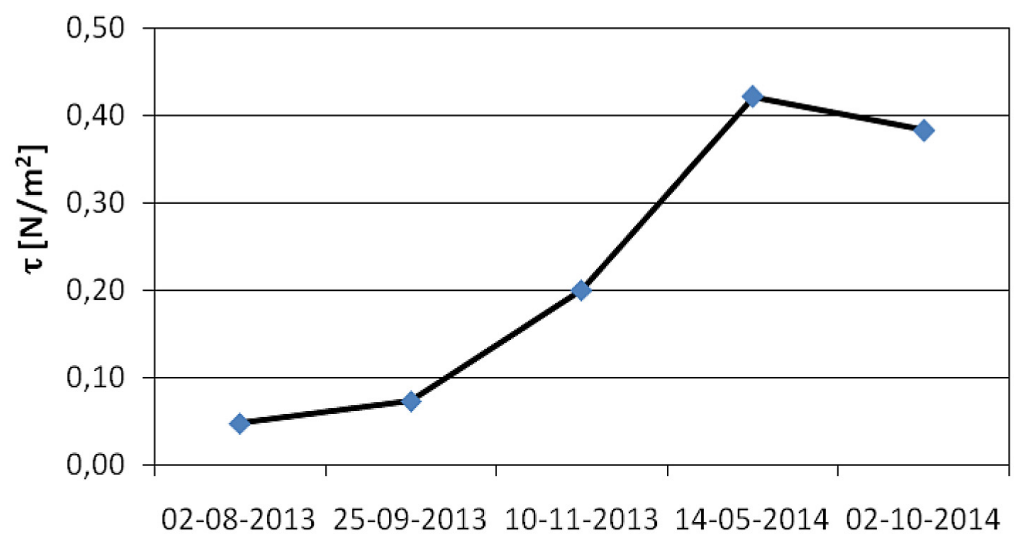

Figure 8. Average shear stress before and after the installation of PBHS over the time under study

Our studies proved that the proposed hydrotechnical structures with plant clumps (Plant Basket Hydraulic Structures) change the hydrodynamic conditions and lead to sediment accumulation and formation of river backwaters before and after the obstacle. The range of observed large erosion and accumulation of bottom material is considerable. Erosion and accumulation processes in the vicinity of water structures develop depending on the life of the facility, hydrological regime and morphology of the riverbed. Diversification of flow characteristics affects the segregation of bed sediment on section of period of weirs. It has examined, among others Bajkowski [2010]. The presence of vegetation zone in rivers and reservoirs influences on fluvial processes.

We have found that PBHS is a relatively lowcost approach of river restoration. It can be relatively easy and quickly installed. Moreover, due to its limited dimensions it does not increase flood risk. The degree of vegetation development and its vertical and horizontal dimensions influence the transport of suspended matter, as well as variation of its dynamics. The research of the suspended load transport in vegetation zone was conducted on a model in scale 1:1 [Pikul and Mokwa 2008] showing that vegetation may cause riverbed roughness changes, bed configuration changes, water level slope changes increase of riverbed erosion resistance and may also cause retention of considerable amount of suspended load transported in the river. The research of Witek [2012] has shown that the type, intensity and location of fluvial processes and forms are connected with natural elements. The influence of most hydraulic engineering constructions is only local and has no impact for functions of the whole river system.

The establishment of ecologically responsive environmental flow regimes is currently a challenge for river management [Dyer and Thoms 2006]. Biological communities in rivers strongly constrained by hydraulic characteristics such as water depth, flow velocity and turbulence. It was proved that variable depth, flow velocity and turbulence stimulate in-stream biodiversity [Dyer and Thoms 2006]. It was proved that channelization can reduce diversity of macroinvertebrates [Kenned and Turner 2011, Strayer et al. 2012] as well as plants and fishes [Strayer et al. 2012]. We have shown the development of differentiated depth and flow velocity patches caused by the PBHS. In this way the positive impact of PBHS on river diversity was shown and their usefulness for river restoration was confirmed.

\section{CONCLUSIONS}

1. The proposed hydrotechnical structures with plant clumps (Plant Basket Hydraulic Structures) change the hydrodynamic conditions and lead to sediment accumulation and formation of river backwaters before and after the obstacle.

2. The erosion and the accumulation processes of bottom material was detected causing the differences in the level of the bottom by about $13 \mathrm{~cm}$.

3. The development of vegetation in the channel bed by the installed structures modifies river flow pattern rising the shear stress from $\tau=$ $0,03 \mathrm{~N} \cdot \mathrm{m}^{-2}$ to $\tau=0,47 \mathrm{~N} \cdot \mathrm{m}^{-2}$.

4. The PBHS showed their usefulness for river restoration by stimulating the fluvial processes and improving hydromorphological state of rivers. 


\section{Acknowledgments}

Work funded by the National Science Centre allocated based on the number of decision DEC2011/01 /B/ST10/06959.

\section{REFERENCES}

1. Bajkowski S. 2010. Sediment segregation on weir of lowland rivers. Ann. Warsaw University of Life Sciences - SGGW, Land Reclamation 42(1), 177-185.

2. Bednarczyk S., Duszyński R. 2008. Hydrauliczne i hydrotechniczne podstawy regulacji i rewitalizacji rzek. Wyd. Politechniki Gdańskiej, Gdańsk.

3. Bolesta S. 1964. Zabudowa roślinna cieków wodnych. PWRiL, Warszawa.

4. Borys M. 2005. Podstawy techniczne modernizacji wałów przeciwpowodziowych i renaturyzacji małych rzek. Rozprawy naukowe i monografie, nr 15.

5. Byczkowski A. Okruszko H. 1996. Zakres badań ukierunkowanych na renaturyzację odwodnionych obszarów w Basenie Środkowym Biebrzy. Zeszyty Problemowe Postępów Nauk Rolniczych, 432, 183-192.

6. Carling P., Whitcombe L., Benson I., Hankin B., Radecki-Pawlik A. 2006. A new method to determine interstitial flow patterns in flume studies of sub-aqueous gravel bed-forms such as fish nests. River Research and Applications, 22, 6, 691-701.

7. Dyer F.J., and Thoms M.C. 2006. Managing river flows for hydraulic diversity: an example of an upland regulated gravel-bed river. River Research and Applications, 22, 257-267.

8. Jędryka E. 2003. Renaturyzacja dolin rzecznych na obszarach zmeliorowanych wyłączonych z produkcji rolniczej na przykładzie obiektów Radunia. Małynka, Tyniewicze, Wydawnictwo IMUZ, Falenty.

9. Kałuża T. 2015. Wpływ planowanych zabiegów renaturyzacyjnych na warunki przepływu rzeki Flinty. Maszynopis Kat. Inżynierii Wodnej i Sanitarnej UP Poznań.

10. Kałuża T., Radecki-Pawlik A., Plesiński K., Walczak N., Szoszkiewicz K. 2015. Changes in local channel morphology and its hydraulic and hydrodynamic consequences following the introduction of plant basket hydraulic structures (PBHS) - the Flinta River example. In: 2nd International Workshop on Hydraulic Structures: Data Validation. Coimbra, Portugal, 7-9 May 2015.
11. Kennedy T.L., Turner T.F. 2011. River channelization reduces nutrient flow and macroinvertebrate diversity at the aquatic terrestrial transition zone. Ecosphere 2, art. 35.

12. Łajczak A. 2006. Regulacja rzeki a zagrożenie powodziowe, na przykładzie Nidy. Infrastruktura i Ekologia Terenów Eiejskich, 4(1), 217-233.

13. Obolewski K., Osadowski Z., Miller M. 2009. Sposoby renaturyzacji małych cieków na przykładzie rzeki Kwaczy (Dolina Słupi). Nauka Przyroda Technologie 3, 3 .

14. Pikul K., Mokwa M. 2008. Wpływ osadnika wstępnego na proces zamulania zbiornika głównego. Przegląd Naukowy. Inżynieria i Kształtowanie Środowiska. SGGW, 40, 185-193.

15. Radecki-Pawlik A. 2014. Hydromorphology of rivers and streams (in Polish). Hydromorfologia rzek i potoków górskich. Agricultural University Publishing House. Wydawnictwo UR w Krakowie. Kraków, pp. 308.

16. Radecki-Pawlik A., Bucała A., Plesiński K., Oglęcki P. 2014. Ecohydrological conditions in two catchments in the Gorce Mountains: Jaszcze and Jamne streams - Western Polish Carpathians. Source of the Document Ecohydrology and Hydrobiology, 14 (3), 229-242

17. Strayer D.L., Findlay S.E.G., Miller D., Malcolm H.M., Fischer D.T., Coote T. 2012. Biodiversity in Hudson River shore zones: influence of shoreline type and physical structure. Aquatic Sciences, 74, 597-610.

18. Szoszkiewicz K., Pietruczuk K., Kałuża T., Strzeliński P. 2014. Opportunities and assumptions of restoration the Wełna and Flinta river (in Polish). Możliwości i założenia renaturyzacji rzek. In: J. Bator, M. Gąbka, E. Jakubas (Eds.) „Koncepcja lasu modelowego w zarządzaniu i ochronie różnorodności biologicznej rzek Wełny i Flinty (Wielkopolska)". Bogucki Wydawnictwo Naukowe Poznań, 127-139.

19. Witek M. 2012. Wpływ zabudowy hydrotechnicznej na współczesne kształtowanie rzeźby koryt rzek ziemi kłodzkiej. Landform Analysis, 9, 91-102.

20. Wołoszyn J., Czamara W., Eliasiewicz R., Krężel J. 1994. Regulacja rzek i potoków. Wyd. Akademii Rolniczej we Wrocławiu, Wrocław.

21. Żelazo J., Popek Z. 2002. Podstawy renaturyzacji rzek. Wydawnictwo SGGW, Warszawa.

22. Żelazo J.. 2006. Renaturyzacja rzek i dolin. Infrastruktura i Ekologia Terenów Wiejskich, 4(1), $11-36$. 